\title{
PENGARUH SUBTITUSI JAGUNG MANIS TERHADAP KUALITAS DADIAH
}

\author{
Fatmawati $^{1}$, Anni Faridah ${ }^{2}$, Elida ${ }^{2}$ \\ ${ }^{1}$ Mahasiswa Program Studi S1 Pendidikan Kesejahteraan Keluarga FPP - UNP \\ ${ }^{2}$ Dosen Jurusan Ilmu Kesejahteraan Keluarga FPP - UNP \\ Email: fatma.wati664@yahoo.co.id
}

\begin{abstract}
Abstrak The purpose of this study was to analyze the effect of sweet corn substitution by $0 \%, 25 \%, 50 \%$ and $75 \%$ on the quality of color, smell, texture and taste of the amount of buffalo milk used. This type of research belongs to a kind of pure experiment using a completely randomized design method of one factor. This research was conducted in Kanagarian Gadut Pakan Raba'a Jorong Lareh Nan Panjang Payakumbuh. The research instrument used is organoleptic test format given to 5 expert panelists namely dadiah farmers. The data obtained is tabulated and do Variant Analysis (ANAVA), if Fcount> Ftable then proceed with Duncan test. The results of the data analysis obtained the highest overall score, yellow color quality is 4.00 (X3), quality smells typical dadiah 4.00 (X0), sweet corn quality 3.33 (X3), soft texture quality $3.80(\mathrm{X0})$, solid texture quality 4.00 (X3), quality of sweet corn flavor $3.53(\mathrm{X} 3)$ and acid taste 3,73 (X3).
\end{abstract}

Keywords: Sweet Corn, Dadiah, Quality.

\section{PENDAHULUAN}

Dadiah merupakan pangan tradisional yang berasal dari Provinsi Sumatera Barat khususnya di daerah Payakumbuh. Menurut Winarno (1984:118), "Dadiah berasal dari susu kerbau yang difermentasi oleh bakteri Asam Laktat seperti golongan Lactobacillus dan Streptococcus". Menurut Azima (1983:10) "Dadiah adalah gumpalan susu yang tidak berubah atau pecah kembali setalah menggumpal, berbau amis dan berasa asam yang dihasilkan dengan cara memeram susu kerbau dalam tabung bambu".

Dapat disimpulkan bahwa dadiah adalah olahan berbahan dasar susu kerbau yang difermentasi selama 2 sampai 3 hari dalam tabung bambu yang merupakan salah satu pangan tradisional khas Sumatera Barat. Dadiah terbuat dari susu kerbau karena susu kerbau lebih kental serta memiliki kandungan gizi yang tinggi dibandingkan susu sapi. Kadungan susu kerbau adalah Protein $6.03 \%$, Lemak $12.40 \%$, Laktosa $3.74 \%$, Mineral $0.89 \%$ dan susu sapi Protein $3.50 \%$, Lemak $4.00 \%$, Laktosa $4.90 \%$, Mineral 0.70\% (Arintonang, 2009), itu sebabnya dadiah sangat baik bagi kesehatan.

Menurut Sisriyenni (2004), bahwa "Dadiah lebih mudah diserap oleh dinding usus manusia sehingga dapat dikonsumsi oleh golongan orang yang tidak tahan laktosa karena laktosa tersebut berubah menjadi asam laktat oleh aktivitas laktose selama proses fermentasi". Dadiah bermanfaat untuk menurunkan kadar kolesterol dalam darah, meningkatkan daya tahan tubuh, 
dan mencegah berbagai penyakit menurut Dinas Peternakan (2016). Ditambahkan oleh Sugitha (1994) mengatakan bahwa "Mengkonsumsi dadiah secara teratur dapat menghindari seseorang dari penyakit jantung dan tumor".

Dadiah merupakan produk susu fermentasi yang tergolong kedalam produk pangan fungsional karena mengandung mikroba hidup yang bermanfaat terhadap kesehatan. Fermentasi pada pembuatan dadiah terjadi secara spontan, artinya fermentasi terjadi secara alami tanpa penambahan lain, hal ini disebabkan karena penggunaan bambu sebagai wadah dadiah yang pada ruas-ruas bambu tersebut terdapat mikroba. Mikroba yang berperan dalam dadiah ini bersifat proteolitik, bakteri probiotik yang utamanya adalah bakteri asam laktat dan bifidobacteria. Istilah probiotik didefinisikan menurut Fuller (1989:225) yaitu "Sebagai suplemen makanan yang mengandung mikroba hidup yang memberi pengaruh menguntungkan bagi kesehatan dengan cara memperbaiki keseimbangan mikroba pada usus". Syarat probiotik adalah tidak patogen, toleran terhadap asam dan garam empedu, mempunyai kemampuan bertahan pada proses pengawetan dan dapat bertahan pada penyimpanan serta memiliki kemampuan memberi efek kesehatan yang sudah terbukti menurut Shortt (1999:56).

$$
\text { Bagi sebagian masyarakat }
$$

Sumatera Barat dadiah diolah sebagai campuran beras emping (terbuat dari beras ketan) yang lebih dikenal dengan sebutan ampiang dadiah. Ampiang dadiah dinikmati dengan cara mencampurkan dadiah, ampiang beras, es serut dan disiram dengan gula merah. Selain ampiang dadiah belum ada olahan lain yang berbahan dasar dadiah yang dapat dinikmati secara langsung tanpa mengurangi nilai tradisonal dari dadiah. Salah satu cara agar dadiah bisa dikonsumsi langsung agar dapat disukai dari berbagai kalangan usia adalah dengan cara menambahakan jagung sebagai rasa alami dan warna sekaligus menambah nilai gizi pada dadiah. Jagung yang digunakan adalah jenis jagung manis (dalam bahasa latin disebut Zae Mays) yang biasanya diolah masyarakat sebagai jagung rebus atau jagung bakar.

Jagung manis merupakan tanaman hortikultura yang banyak disukai masyarakat, karena memiliki kandungan sukrosa yang lebih tinggi dibandingkan dengan jagung biasa. Jagung manis ini memiliki kandungan gizi yang tinggi, yaitu energi (96 kal), protein $(3,5 \mathrm{~g})$, lemak $(1,0 \mathrm{~g})$, karbohidrat (22,8 g), kalsium (3,09 mg), fosfor $(111,0 \mathrm{mg})$, besi $(0,7 \mathrm{mg})$, vitamin A (400 SI), vitamin B (0,15 $\mathrm{mg}$ ), vitamin C (12 mg), dan air (72,7 g) menurut Pabbage dkk (2008).

Selain itu jagung juga merupakan jenis pangan prebiotik, subtansi prebiotik memiliki dampak positif bagi mikroflora usus terutama bakteri probiotik yang berfungsi sebagai subtansi makanan dari probiotik menurut Hui (2012:55). Maka dari itu jika pencampuran dadiah sebagai pangan probiotik dan jagung manis sebagai pangan prebiotik pada 
penelitian ini akan menghasilkan sebuah pangan baru dengan istilah pangan sinbiotik. Sinbiotik merupakan istilah yang digunakan dalam penamaan pada produk makanan yang didalamnya terdapat campuran antara probiotik dan prebiotik.

Berdasarkan literatur yang penulis baca, belum ada penelitian tentang pengaruh subtitusi jagung manis terhadap kualitas dadiah. Penelitian dadiah dan jagung manis yang sudah pernah dilakukan adalah (1) pembuatan es krim ubi jalar ungu dari dadiah oleh Pradasari Pertiwi (2016), (2) pengaruh subtitusi dadiah terhadap kualitas es krim coklat oleh Mery Yulianti Putri (2017), (3) pembuatan jagung manis pada pembuatan es krim oleh Atika Dwi Juwita (2016). Penulis telah melakukan pra penelitian dengan penggunaan jagung manis sebagai subtitusi terhadap kualitas dadiah. Penelitian ini bertujuan untuk menganalisis pengaruh subtitusi jagung manis terhadap kualitas dadiah.

\section{METODE PENELITIAN}

Jenis penelitian ini adalah penelitian eksperimen murni yaitu melakukan percobaan langsung pada pembuatan dadiah dengan subtitusi jagung manis sebanyak 0\%, 25\%, 50\% dan $75 \%$, dari jumlah susu kerbau yang digunakan. Data yang digunakan dalam penelitian ini adalah data primer. Data primer adalah data yang langsung diambil dari panelis penelitian meliputi data yang menggambarkan kualitas dadiah dengan subtitusi jagung manis melalui uji organoleptik meliputi: warna, aroma, tekstur, dan rasa. Penelitian ini dilakukan di Kenagarian Gadut Pakan Raba'a Jorong Lareh Nan Panjang Nagari Batu Payuang Payakumbuh pada bulan September 2017. Objek penelitian adalah dadiah dengan subtitusi jagung manis $0 \%$, $25 \%$, 50\% dan $75 \%$, untuk dapat menganalisa kualitas dadiah yang meliputi: warna, aroma, tekstur dan rasa. Sumber data adalah melakukan uji organoleptik dengan 5 orang panelis ahli yaitu petani dadiah. Setelah melakukan uji oerganoleptik dan memperoleh data, data ditabulasi dalam bentuk tabel dan dianalisa dengan analisis varian (ANAVA). Jika Fhitung > Ftabel maka akan dilanjutkan dengan uji duncan.

Pada penelitian ini yang digunakan adalah resep dari Bapak Tongsek (2016). Bahan yang digunakan dalam penelitian ini adalah susu kerbau segar $(500 \mathrm{ml})$, selanjutnya substitusi jagung manis $25 \%, 50 \%$, dan $75 \%$ dari jumlah susu kerbau yang digunakan. Adapun diagram alir pembuatan dadiah jagung manis dapat dilihat pada Gambar 1 berikut: 


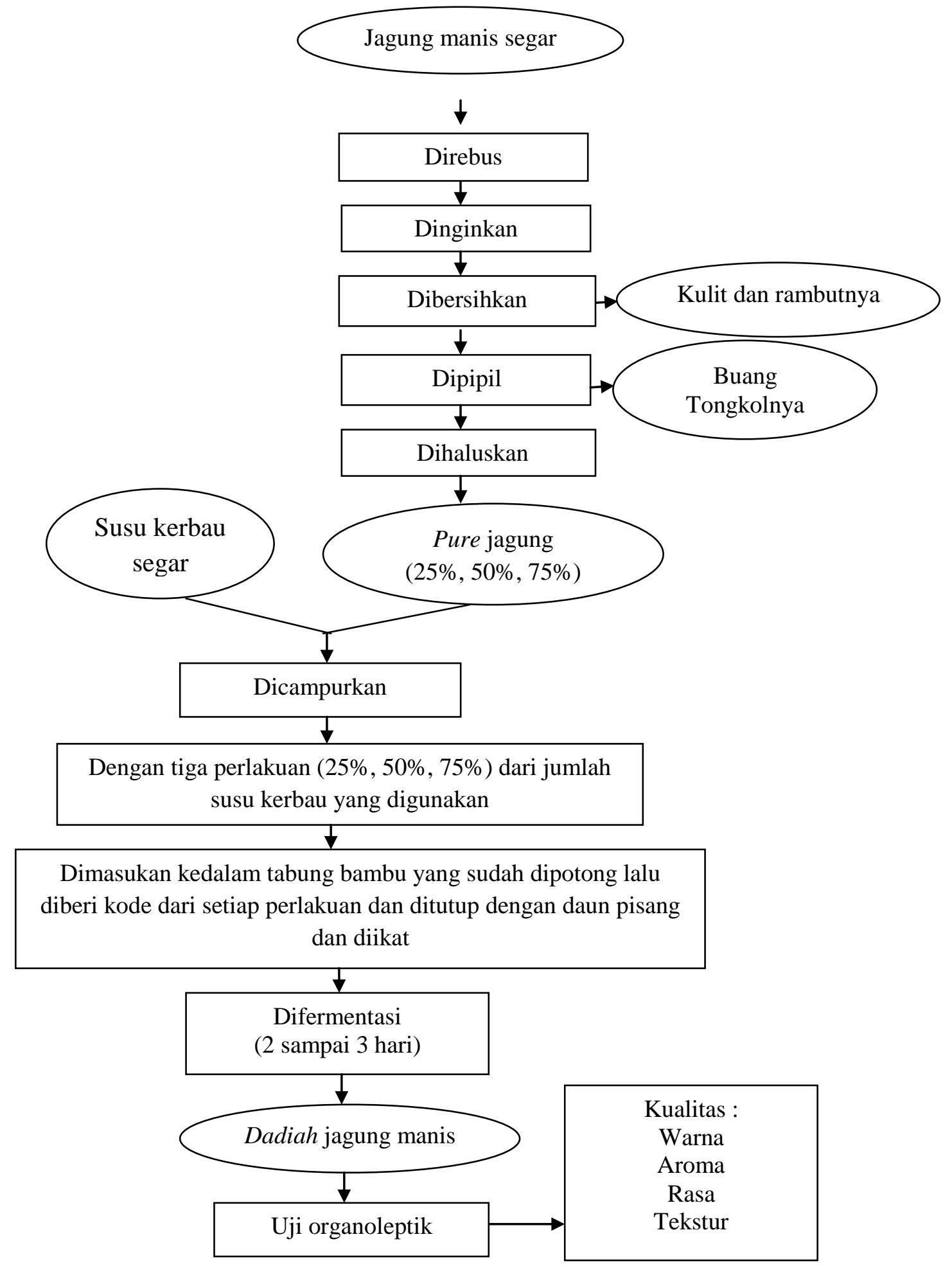

Gambar 1. Proses Pembuatan Dadiah Jagung Manis 
HASIL DAN PEMBAHASAN

1. Hasil Penelitian

a. Deskripsi Data Kualitas Dadiah dengan Subtitusi Jagung Manis $0 \%, 25 \%, 50 \%$ dan $75 \%$.
Perbandingan deskripsi data kualitas dadiah dengan subtitusi jagung manis 0\%, 25\%, $50 \%$ dan $75 \%$ meliputi warna, aroma, tekstur dan rasa dapat dilihat pada gambar berikut:

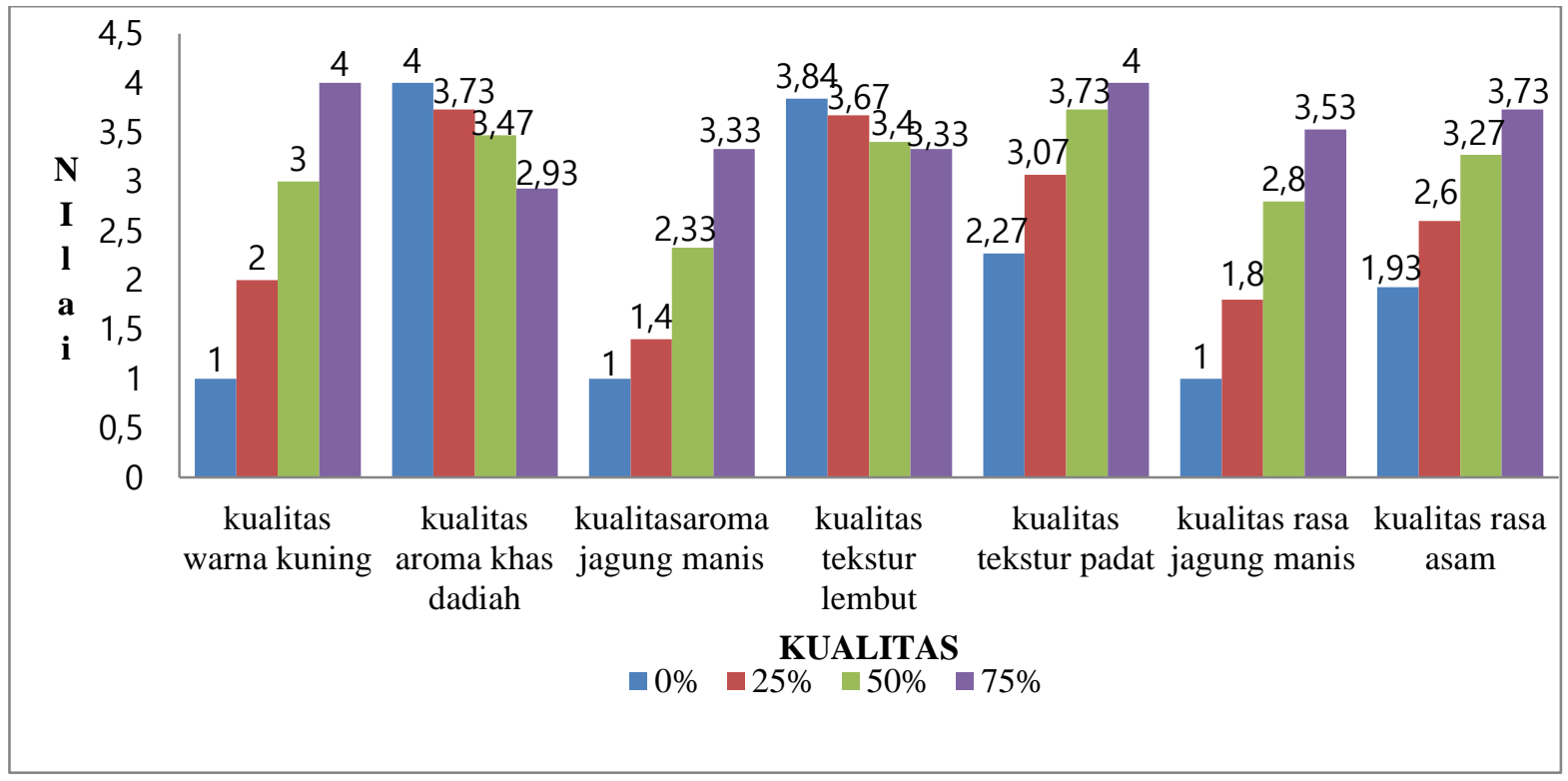

\section{Gambar 2. Uji Jenjang Kualitas Dadiah}

Berdasarkan diatas dapat dijelaskan bahwa:

1) Warna Kuning Dadiah dengan Substitusi Jagung Manis 0\%, 25\%, 50\% dan $75 \%$

Kualitas warna kuning terdapat perbedaan nilai antar perlakuan yaitu $\mathrm{X}_{0}(1.00), \mathrm{X}_{1}$ (2.00), $X_{2}$ (3.00), dan $X_{3}$ (4.00) dimana $X_{0}$ tidak berwarna kuning, $X_{1}$ kurang berwarna kuning, $\mathrm{X}_{2}$ cukup berwarna kuning dan $X_{3}$ berwarna kuning. Hal ini dikarenakan penggunaan bahan yaitu jagung manis terhadap setiap perlakuan pada pembuatan dadiah.
2) Aroma Khas Dadiah dan Aroma Jagung Manis Dadiah dengan Substitusi Jagung Manis 0\%, 25\%, $50 \%$ dan $75 \%$

Kualitas aroma khas dadiah yaitu pada $\mathrm{X}_{0}$ (4.00), $X_{1}$ (3.73), $X_{2}$ (3.47) dan $X_{3}$ (2.93) dimana $X_{3}$ tidak beraroma khas dadiah, $\mathrm{X}_{2}$ kurang beraroma khas dadiah, $\mathrm{X}_{1}$ cukup khas dadiah, dan $\mathrm{X}_{0}$ berada dalam kategori beraroma khas dadiah.

Kualitas aroma jagung manis pada $\mathrm{X}_{0}$ (1.00), $\mathrm{X}_{1}$ (1.40), $\mathrm{X}_{2}$ (2.33) dan $\mathrm{X}_{3}$ (3.33) dimana $\mathrm{X}_{0}$ tidak 
beraroma jagung, $\mathrm{X}_{1}$ kurang beraroma jagung, $X_{2}$ cukup beraroma jagung, dan $X_{3}$ berada dalam kategori beraroma jagung manis. Kedua aroma tersebut dihasilkan karena penggunaan bahan yaitu jagung manis terhadap setiap perlakuan pada pembuatan dadiah.

3) Tekstur Lembut dan Tekstur Padat Dadiah dengan Substitusi Jagung Manis 0\%, 25\%, 50\% dan $\mathbf{7 5 \%}$

Kualitas tekstur lembut pada $\mathrm{X}_{0}$ (3.80), $\mathrm{X}_{1}$ (3.67), $X_{2}$ (3.40), dan $X_{3}$ (3.33) dimana $X_{3}$ tidak bertekstur lembut, $\mathrm{X}_{2}$ kurang bertekstur lembut, $X_{1}$ cukup bertekstur lembut, dan $\mathrm{X}_{0}$ berada dalam kategori bertekstur lembut dari dadiah.

Kualitas tekstur padat pada $\mathrm{X}_{0}$ (2.27), $\mathrm{X}_{1}$ (3.07), $\mathrm{X}_{2}$ (373), $X_{3}$ (4.00) dimana $X_{0}$ tidak bertekstur padat, $\mathrm{X}_{1}$ kurang padat, $\mathrm{X}_{2}$ cukup bertekstur padat, dan $\mathrm{X}_{3}$ berada dalam kategori bertekstur padat. Kedua tekstur tersebut dihasilkan karena penggunaan bahan yaitu jagung manis terhadap setiap perlakuan pada pembuatan dadiah.
4) Rasa Jagung Manis dan Rasa Asam Dadiah dengan Substitusi Jagung Manis 0\%, $25 \%, 50 \%$ dan $75 \%$

Kualitas rasa jagung pada $\mathrm{X}_{0}$ diperoleh skor 1.00 , $\mathrm{X}_{1}$ diperoleh skor $1.80, \mathrm{X}_{2}$ diperoleh skor 2.80 , dan $\mathrm{X}_{3}$ diperoleh skor 3.53 dimana $\mathrm{X}_{0}$ tidak berasa jagung, $\mathrm{X}_{1}$ kurang berasa jagung, $\mathrm{X}_{2}$ cukup berasa jagung, dan $\mathrm{X}_{3}$ berada dalam kategori berasa jagung.

kualitas rasa asam pada $\mathrm{X}_{0}$ diperoleh skor 1.93 , $\mathrm{X}_{1}$ diperoleh skor $2.60, \mathrm{X}_{2}$ diperoleh skor 3.27, $\mathrm{X}_{3}$ diperoleh skor 3.73 dimana $\mathrm{X}_{0}$ tidak berasa asam, $\mathrm{X}_{1}$ kurang berasa asam, $X_{2}$ cukup berasa asam, dan $\mathrm{X}_{3}$ berada dalam kategori berasa asam. Kedua rasa tersebut dihasilkan karena penggunaan bahan yaitu jagung manis terhadap setiap perlakuan pada pembuatan dadiah.

\section{b.Uji Hipotesis Kualitas Dadiah} dengan Subtitusi Jagung Manis $0 \%, 25 \%, 50 \%$ dan $75 \%$.

Hasil

statistik

membuktikan bahwa Ha diterima (Fhitung > Ftabel) artinya terdapat pengaruh yang nyata pada kualitas warna kuning, kualitas aroma khas dadiah, aroma jagung manis, kualitas tekstur padat, rasa jagung manis dan rasa asam. Sedangkan pada tekstur lembut tidak 
berpengaruh nyata karena $\mathrm{Ha}$ ditolak (Fhitung < F tabel).

Tabel 1. Hasil Analisis Varian (ANAVA)

\begin{tabular}{|c|l|c|}
\hline \multicolumn{1}{|c|}{ Variabel } & \multicolumn{1}{|c|}{ Indikator } & $\begin{array}{c}\text { Hasil uji statistik } \\
\text { Fhitung> Ftabel 5\% }\end{array}$ \\
\hline \multirow{4}{*}{$\begin{array}{c}\text { Kualitas Dadiah Jagung } \\
\text { Manis }\end{array}$} & Warna kuning & $44.61>3.49$ \\
\cline { 2 - 3 } & Aroma khas dadiah & $37.33>3.49$ \\
\cline { 2 - 3 } & Aroma jagung manis & $188.58>3.49$ \\
\cline { 2 - 3 } & Tekstur lembut & $1.98<3.49$ \\
\cline { 2 - 3 } & Tekstur padat & $35.13>3.49$ \\
\cline { 2 - 3 } & Rasa jagung manis & $126.00>3.49$ \\
\cline { 2 - 3 } & Rasa asam & $98.06>3.49$ \\
\hline
\end{tabular}

Berdasarkan tabel 1, kualitas yang berpengaruh nyata yaitu kualitas warna kuning, kualitas aroma khas dadiah, aroma jagung manis, kualitas tekstur padat, rasa jagung manis dan rasa asam., untuk itu dilanjutkan dengan uji duncan dapat dilihat pada tabel 2 dibawah ini:

Tabel 2. Uji Lanjut Duncan Multiple Range Test terhadap kualitas dadiah jagung manis

\begin{tabular}{|c|c|c|c|c|c|}
\hline Indikator & Sampel & $\mathbf{A}$ & B & $\mathbf{C}$ & D \\
\hline \multirow{4}{*}{ Warna Kuning } & $\mathrm{X}_{3}$ & 4.00 & & & \\
\hline & $\mathrm{X}_{2}$ & & 3.00 & & \\
\hline & $\mathrm{X}_{1}$ & & 2.00 & & \\
\hline & $\mathrm{X}_{0}$ & & 1.00 & & \\
\hline \multirow{4}{*}{ Aroma Khas Dadiah } & $\mathrm{X}_{3}$ & 2.93 & & & \\
\hline & $\mathrm{X}_{2}$ & & 3,47 & & \\
\hline & $\mathrm{X}_{1}$ & & & 3,73 & \\
\hline & $\mathrm{X}_{0}$ & & & & 4.00 \\
\hline \multirow{4}{*}{ Aroma Jagung Manis } & $\mathrm{X}_{3}$ & 3.33 & & & \\
\hline & $\mathrm{X}_{2}$ & & 2.33 & & \\
\hline & $\mathrm{X}_{1}$ & & & 1.40 & \\
\hline & $\mathrm{X}_{0}$ & & & & 1.00 \\
\hline \multirow{4}{*}{ Tekstur Padat } & $\mathrm{X}_{3}$ & 2.27 & & & \\
\hline & $\mathrm{X}_{2}$ & 3.07 & & & \\
\hline & $\mathrm{X}_{1}$ & 3.73 & & & \\
\hline & $\mathrm{X}_{0}$ & 4.00 & & & \\
\hline \multirow{4}{*}{ Rasa Jagung Manis } & $\mathrm{X}_{3}$ & 3.53 & & & \\
\hline & $\mathrm{X}_{2}$ & & 2.80 & & \\
\hline & $\mathrm{X}_{1}$ & & 1.80 & & \\
\hline & $\mathrm{X}_{0}$ & & & 1.00 & \\
\hline \multirow{4}{*}{ Rasa Asam } & $\mathrm{X}_{3}$ & 3.73 & & & \\
\hline & $\mathrm{X}_{2}$ & & 3.27 & & \\
\hline & $\mathrm{X}_{1}$ & & & 2.60 & \\
\hline & $\mathrm{X}_{0}$ & & & & 1.93 \\
\hline
\end{tabular}


2. Pembahasan

$\begin{array}{lrr}\text { a. Pengaruh } & \text { Dadiah } & \text { dengan } \\ \text { Subtitusi } & \text { Jagung } & \text { Manis } \\ \text { terhadap } & \text { Kualitas } & \text { Warna } \\ \text { Kuning } & & \end{array}$

Berdasarkan

hasil

ANAVA Ha diterima yang artinya terdapat pengaruh signifikan terhadap kualitas warna kuning dadiah dengan substitusi jagung manis. Hal ini membuktikan bahwa substitusi jagung manis yang semakin banyak akan mempengaruhi warna pada dadiah. Warna dari dadiah adalah kuning yang disebabkan oleh pewarnaan alami yang terdapat dalam jagung manis. Warna merupakan salah satu penentu pada sebuah produk sesuai dengan teori menurut Sayuti (1992:11) "Dilihat dari warnanya, dadiah yang baik adalah dadiah yang terbuat dari susu kerbau dengan ciri-ciri berwarna putih dan hampir seperti tahu dan dapat dimakan dengan sendok". Dapat dinyatakan bahwa semakin banyak dadiah yang disubstitusi jagung manis warnanya akan berubah.

b. Pengaruh Dadiah dengan Subtitusi Jagung Manis terhadap Kualitas Aroma Khas Dadiah dan Aroma Jagung Manis

Berdasarkan hasil ANAVA dapat dinyatakan bahwa substitusi jagung manis yang digunakan pada dadiah sedikit dapat mengurangi aroma dadiah dan sedikit tercium aroma jagung manis, sehingga aroma khas dadiah masih mendominasi dari setiap perlakuaan karena aroma susu kerbau sangat menyengat dibandingan aroma jagung oleh sebab itu aroma susu pada dadiah jagung masih tercium. Aroma dapat mempengaruhi minat konsumen terhadap produk sesuai dengan pendapat Sugitha (1999:115) "Dadiah berwarna putih bersih bertekstur padat dengan aroma khas dadiah".

c. Pengaruh Dadiah dengan Subtitusi Jagung Manis terhadap Kualitas Tekstur Lembut dan Tekstur Padat

Berdasarkan hasil ANAVA pada kualitas tekstur lembut Ho diterima yang artinya tidak terdapat perbedaan pengaruh yang signifikan terhadap kualitas tekstur lembut dadiah dengan substitusi jagung manis dari masing-masing perlakuan. Pada kualitas tekstur padat $\mathrm{Ha}$ dapat diterima yang artinya terdapat perbedaan pengaruh yang signifikan terhadap kualitas tekstur padat dengan substitusi jagung manis dari masing-masing perlakuan, ini dapat dinyatakan bahwa substitusi jagung manis yang digunakan pada tekstur lembut adalah Ho dan tekstur padat Ha, menurut Sugitha, dkk. (1999:110) "Dadiah bertekstur lembut, padat dan kental". 


\section{d. Pengaruh Dadiah dengan Subtitusi Jagung Manis terhadap Kualitas Rasa Jagung Manis dan Rasa Asam}

Berdasarkan hasil ANAVA dapat dinyatakan bahwa substitusi jagung manis terhadap kualitas rasa jagung dan rasa asam dadiah dengan jumlah yang berbeda pada masing-masing perlakuan dapat memberikan pengaruh nyata terhadap dadiah karena asam dari dadiah lebih dominan dibandingkan rasa jagung oleh karena itu rasa jagung menjadi berkurang karena bercampur dengan rasa asam dari dadiah. Menurut Sayuti (1992) "Dadiah memiliki rasa asam yang khas dan tidak berbau tengik". Tetapi dalam penelitian dadiah ini rasa yang dominan ditangkap oleh indera pengecap adalah rasa asam dan jagung. Ini terjadi diakibatkan pencampuran jagung pada dadiah, dan difermentasi sehingga berpengaruh terhadap rasa jagung.

\section{KESIMPULAN DAN SARAN}

\section{Simpulan}

Hasil uji statistik membuktikan bahwa $\mathrm{Ha}$ diterima (Fhitung>Ftabel) yang artinya terdapat pengaruh yang signifikan terhadap kualitas warna, kualitas aroma khas dadiah, aroma jagung manis, kualitas tekstur padat, rasa jagung manis dan rasa asam dadiah jagung manis yaitu warna kuning terbaik terdapat pada $\mathrm{X}_{3}$ (4.00), aroma khas dadiah terbaik terdapat pada $\mathrm{X}_{0} \quad(4.00), \quad$ aroma jagung terbaik terdapat pada $X_{3}$ (3.33), tekstur padat terbaik terdapat pada $\mathrm{X}_{3}$ (4.00), rasa jagung terbaik terdapat pada $\mathrm{X}_{3}$ (3.53) dan rasa asam terbaik terdapat pada $X_{3}(3,73)$. Sedangkan pada kualitas tekstur lembut tidak terdapat pengaruh yang nyata karena Ha ditolak (Fhitung $<$ Ftabel).

\section{Saran}

a. Agar pembuatan pure jagung manis menghasilkan warna, aroma, rasa dan tekstur yang baik jagung manis yang digunakan adalah jagung manis yang masih segar.

b. Pada penghalusan jagung manis tidak dicampur dengan air, karena jagung manis yang digunakan sudah mengandung banyak air. Jagung manis ini mengandung banyak air karena tidak bisa menghasilkan pati sehingga tekstur biji jagungnya mengandung air dan memiliki rasa yang manis sehingga cara ini benar-benar memberikan pengaruh terhadap kualitas pure jagung yang diinginkan dari segi warna, aroma, rasa dan tekstur.

c. Pemotongan tabung bambu yang akan digunakan sebaiknya dilakukan 1 hari sebelum digunakan, karena tabung mabu yang segar didalam ruas-ruasnya menggadung air dan serbuk sehingga tabung bambu yang akan digunakan harus dijemur terlebih dahulu agar air bambu nya kering sempurna sebelum digunakan lalu 
di gosok bagian dalam ruasnya menggunakan lap bersih supaya serbuk bambunya hilang, hal ini sanggat berpengaruh nantinya terhadap kualitas dadiah yang dihasilkan saat peroses fermentasi.

d. Dadiah yang difermentasi cukuplah ditaruh atau disimpan pada suhu ruang, karena jika ditaruh dalam lemari es pada susu kerbaunya akan memberikan pengaruh terhadap kualitas susu kerbaunya, yaitu warna susu kerbau menjadi jalang atau pucat. Dan jika dadiahnya sudah atau menggumpal lalu dimasukan kedalam kulkas juga akan memberikan pengaruh pada teksturnya yaitu pada dadiah akan terlihat pecah-pecah dan rengkah sehingga permukaan dadiah tidak lagi lembut dan kental melainkan kering dan pecah-pecah, itu sebabnya dadiah cukup ditaruh pada suhu ruang.

e. Dari hasil penelitian ini dapat disimpulkan bahwa produk ini tidak layak untuk dilakukan penelitian lanjutan, hal ini dikarenakan menambahkan jagung justru menambah rasa asam pada dadiah sehingga dadiah menjadi tidak enak untuk dinikmati secara langsung, hal ini bisa disebabkan karena sifat jagung rebus yang bila didiamkan semalaman akan terasa asam dan basi dan hal ini yang memberikan pengaruh pada dadiah yang dimana dadiah itu sendiri juga sudah memiliki rasa asam yang khas dari hasil fermentasi.

\section{DAFTAR RUJUKAN}

Aritonang, R. Labirin, R. 2009. Kandungan Susu Kerbau dan Sapi. Jakarta. Ghalia Indonesia.

Atika Dwi Juwita. 2016. Penggunaan Jagung Manis Pada Pembuatan Es Krim. Proyek Akhir. Padang: FPP UNP.

Azima. F. 1983. Studi Tentang Dadiah. Fakultas Teknologi Pertanian. Universitas Gadjah Mada. Yogyakarta.

Dinas Peternakan. 2016. Manfaat Dadiah Bagi Kesehatan. (http://www.sumbarprov.go.id/d etail/news/7915. Diakses pada 09 Agustus 2016).

Fuller, R. 1989. Bacteria Associated with The Intestinal Wall of The Fowl (Gallus Domesticus). Journal Of Applied Bacteriology 34, 617-622.

Hui. 2012. Encylopedia Of Food Science and Technology. Volume II. Johon Willey and Sons Inc, Canada.

Meri Yulianti Putri. 2017. Pengaruh Subtitusi Dadiah Terhadap Kualitas Es Krim Coklat. Skripsi. Padang : FPP UNP.

Meri Yulianti Putri. 2017. Pengaruh Subtitusi Dadiah Terhadap Kualitas Es Krim Coklat. Skripsi. Padang : FPP UNP. 
Pabbage,Masdianadan Manik. (2008). Membuat Es Krim Yang Sehat. Surabaya: TrubusAgrisarana.

Pradasari Pertiwi. 2016. Pembuatan Es Krim Ubi Jalar Ungu Dari Dadiah. Proyek Akhir. Padang : FPP UNP.

Sayuti. K. 1992. Studi Nilai Sosial dan Konsumsi Makanan Tradisional Di Sumatera Barat. Artikel Sosial.

(http://www.google.co.id/amp/s/ prakoso93.wordpress.com/2014/ 03/08/dadih-makanantradisional-yangfungsional/amp/. Diakses 17 Juli 2017).

Shortt, H. and K. Keasey. 1999. Managerial Ownership And Performance Of Firns : Evidence From The UK. Journal Of Corporate Finance 5. Page : 79-100.

Sisriyenni Dwi dan Yuyu Zurruyati. 2004. Fermentasi Susu Kerbau. (http://fermentasisusukerbau.blo gsport.com $/ 2004 / 22 / \mathrm{html}$. Diakses 15 November 2016).

Sugitha. I.M. 1994. Teknologi Pembuatan Dadiah. Kakultas Peternakan Universitas Andalas. Padang.

Sugitha. I.M., ddk 1999. Kandungan Gizi, Vitamin dan Kualitas Dadiah Dibuat Dalam Tabung Plastik Dengan Sarter Strepococcus Lactis. Jurnal Peternakan dan Lingkungan. Vol. 4 No.3 Fak. Peternakan UNAND Padang.
Sugiyono. 2004. Kimia Pangan. Yogyakarta: Fakultas Teknik UNY.

Winarno, F.G. 1984. Kimia Pangan Dan Gizi. Jakarta : Gramedia Pustaka Utama. 